\title{
The Japanese Market for Corporate \\ Control and Managerial Incentives
}

\author{
Jun-Koo Kang \& Takeshi Yamada
}

Working Paper No. 107

\author{
Jun-Koo Kang \\ A. Gary Anderson Graduate School of Management \\ University of California \\ Riverside, CA \\ Takeshi Yamada \\ School of Business and Management \\ Hong Kong University of Science \& Technology \\ Kowloon, Hong Kong
}

This paper was presented at the conference Emerging Trends in Japanese Financial Markets held at Columbia University on December 8-9, 1995. The conference was sponsored by the

Center on Japanese Economy and Business and organized by Professor Yasushi Hamao

\author{
Working Paper Series \\ Center on Japanese Economy and Business \\ Graduate School of Business \\ Columbia University \\ February 1996
}




\title{
The Japanese market for corporate control and managerial incentives
}

\author{
Jun-Koo Kang* \\ A. Gary Anderson Graduate School of Management \\ University of California \\ Riverside, CA 92521 \\ U.S.A. \\ (909) 787-4589 \\ JKANG@ORANGE.UCR.EDU \\ Takeshi Yamada* \\ School of Business and Management \\ Hong Kong University of Science and Technology \\ Kowloon, Hong Kong \\ (852) 2358-7687 \\ TYAMADA@USTHK.UST.HK
}

January, 1996

\begin{abstract}
We examine bidder returns in Japanese mergers from 1976 to 1990 . Using a comprehensive sample of 104 Japanese acquiring firms, we find that shareholders of Japanese bidders experience a significant positive abnormal return of $1.41 \%$. Bidder returns are higher when firms acquire targets in the same industry, when their managers performed well before the merger, and when their managers acquire relatively large targets. We also find that bidder returns increase with the bidder's leverage and the bidder's ties to financial institutions through borrowings. Our evidence is consistent with the view that managerial incentives affect a firm's investment decisions and therefore firm value, and that these incentives are affected by the internal governance mechanisms that control managerial discretion.
\end{abstract}

\footnotetext{
* We are grateful for comments from Warren Bailey, Y. Peter Chung, Chung Gee, Takeo Hoshi, Hasung Jang, Herb Johnson, Andrew Karolyi, Kenneth Kim, Phill Sang Lee, Frank Lichtenberg, David Mayers, Sang-Koo Nam, Henry Oppenheimer, Anil Shivdasani, Yong-sup Yun, participants at the Emerging Trends in Japanese Financial Markets Conference at the Columbia University and at a seminar at the Korea University, and for useful conversations with Kenneth Singleton. Please address correspondence to Jun-Koo Kang.
} 


\title{
The Japanese market for corporate control and managerial incentives
}

\begin{abstract}
We examine bidder returns in Japanese mergers from 1976 to 1990 . Using a comprehensive sample of 104 Japanese acquiring firms, we find that shareholders of Japanese bidders experience a significant positive abnormal return of $1.41 \%$. Bidder returns are higher when firms acquire targets in the same industry, when their managers performed well before the merger, and when their managers acquire relatively large targets. We also find that bidder returns increase with the bidder's leverage and the bidder's ties to financial institutions through borrowings. Our evidence is consistent with the view that managerial incentives affect a firm's investment decisions and therefore firm value, and that these incentives are affected by the internal governance mechanisms that control managerial discretion.
\end{abstract}




\section{The Japanese market for corporate control and managerial incentives}

There has been much debate on whether the actions of Japanese corporate governance mechanisms are consistent with shareholder wealth maximization. ${ }^{1}$ Several researchers argue that while the corporate governance mechanisms in Japan are fundamentally different from those in the U.S., alternative governance systems in Japan provide managers incentives to maximize firm value. For instance, Aoki (1990) and Sheard (1989) argue that Japanese banks, which are allowed to hold a firm's equity, perform an important governance role and discipline managers when their performance is poor. In contrast to this view, others argue that the absence of hostile acquisitions, the absence of outside directors, and the crossholdings among many Japanese firms insulate Japanese managers from outside influence and thus leave them unconstrained.

In spite of considerable controversy over the importance of corporate governance mechanisms in Japan and their effects on managerial incentives and firm value, there is little empirical evidence on the links between them. Using a comprehensive sample of 104 Japanese mergers during the 15 year period from 1976 to 1990, this paper examines the effects of bidding managers' incentives and corporate control mechanisms on bidding firm value. Managerial objectives and corporate governance mechanisms are likely to play an important role when managers consider acquiring other firms, because corporate control transactions usually involve major organizational changes that have direct effects on firm value. Therefore, one approach to investigating whether Japanese managers have different objectives from their American counterparts and whether the effects of actions by corporate governance mechanisms on firm value are different between the U.S. and Japan is to study the cross-sectional variation of bidder announcement returns, focusing on factors that can influence managerial incentives. Furthermore,

\footnotetext{
${ }^{1}$ For a discussion of the Japanese governance mechanism, see Aoki (1984, 1990), Nakatani (1984), Kester (1986, 1990), Ballon and Tomita (1988), Sheard (1989), Prowse (1990), Hoshi, Kashyap, and Scharfstein (1991), and Kaplan (1994).
} 
the stock-price reaction to the initial public announcement of domestic mergers for Japanese acquiring firms has not been empirically examined by the previous studies. ${ }^{2}$

Considerable evidence in the U.S. suggests that bidder returns in mergers and acquisitions are either affected by bidding managers' incentives or related to internal governance systems which serve as mechanisms to control managerial discretion. For example, Morck, Shleifer, and Vishny (1990) show that for a sample of 326 U.S. mergers between 1975 and 1987, bidder returns are significantly affected by management's objective function: Returns to bidders are lower when they acquire targets operating in different industries and when their managers performed poorly before the merger. In a similar context, Lang, Stulz, and Walkling (1989) find that the largest total takeover gain occurs when bidders with high Tobin's $Q$ acquire targets with low Tobin's Q. In related papers, Lewellen, Loderer, and Rosenfeld (1985) find that bidder returns are positively related to the bidder's managerial equity ownership; Maloney, McCormick, and Mitchell (1993) find that bidder returns increase with their leverage levels; and Byrd and Hickman (1992) show that bidder returns are less negative for firms on whose boards at least half the seats are held by independent outside directors. These results are generally consistent with the view that managerial incentives affect a firm's investment decisions and therefore firm value, and that these incentives, in turn, are affected by bidder-specific characteristics which serve as incentive control mechanisms.

To examine whether firm value is related to managerial incentives in Japanese firm takeovers, we first classify our sample of 104 bidders into subsamples of interest based on bidding managers' motives for mergers. If certain types of mergers are driven by bidding managers' incentives to maximize their private benefits, we expect that those mergers systematically lead to lower returns to shareholders of acquiring firms. To measure the potential difference in managerial incentives in mergers, we follow Morck, Shleifer, and Vishny (1990) and compare returns to bidders that acquire targets in the same industry to those in a different industry. As argued by Amihud and Lev (1981), managers who have incentives to lower the variability of their personal

\footnotetext{
${ }^{2}$ See Jensen and Ruback (1983) and Jarrell, Brickley, and Netter (1988) for evidence on the announcement returns for acquiring firms in the U.S.
} 
wealth may undertake value-reducing acquisitions. Managers who want to reduce the risk to their human capital may choose to engage in conglomerate mergers, even though these activities can adversely affect shareholder wealth. The view that unrelated diversification decreases firm value is supported by several empirical studies. Lang and Stulz (1994), Berger and Ofek (1995), and Comment and Jarrell (1995) provide evidence that diversification represents a suboptimal managerial strategy resulting in a value loss.

Using industrial relationships between bidders and targets, we then extend our analysis to examine whether managers of keiretsu firms face different incentives from those facing managers of U.S. or non-keiretsu firms. One important feature of Japanese financial characteristics is that many Japanese firms belong to industrial groups known as keiretsu, where each group's bank plays a leading role in the financial activities within the group. Firms belonging to a keiretsu are bound together by a nexus of explicit and implicit contracts, and maintain substantial business ties with other firms in the group. ${ }^{3}$ As argued in Kang and Stulz (1996), managers in keiretsu firms are more likely to focus on the wealth of their long-term investors, who are mostly other keiretsu members. Since these keiretsu firms often buy and sell goods and services from one another [Berglof and Perotti (1994)] and they are connected by an extensive arrangement of reciprocal shareholding agreements, the typical manager in a keiretsu firm may face incentives quite different from those of the typical U.S. manager. In this context, Kester (1991) argues that Japanese managers in keiretsu firms have a strong incentive to maximize the overall value of many different stakeholders, including other keiretsu member firms. ${ }^{4}$ If managers of keiretsu firms are more concerned about other keiretsu members and consequently acquire targets operating in different industries to maximize the aggregate value among keiretsu firms, then unrelated diversification

\footnotetext{
${ }^{3}$ Currently, there are 6 major industrial groups in Japan (Mitsubishi, Mitsui, Sumitomo, Fuyo, DKB, and Sanwa), which form the core of Japan's premier keiretsu. These groups are characterized by horizontal connections over a wide spectrum of industries, such as mining, construction, manufacturing, wholesale and retail, and financial and insurance.

${ }^{4}$ See also Kester (1990) and Porter (1992) for an extensive discussion of the difference in managerial objectives faced by Japanese managers. Kang and Stulz (1996) argue that Japanese managers issue shares based on different considerations than American managers, and show that Japanese managers are more interested in maximizing the wealth of long-term shareholders rather than that of short-term shareholders.
} 
pursued by managers of keiretsu firms may not necessarily represent managerial self-interest, and thus will have a different effect on firm value compared to unrelated diversification pursued by managers of non-keiretsu firms.

We also compare returns to bidders whose previous stock returns before the merger were above their industry averages to returns to bidders whose previous stock returns were below their industry averages. This classification is based on the possibility that managers who performed poorly before the merger are more likely to make bad acquisitions because of their lack of managerial ability. Shleifer and Vishny (1989) develop a model where a manager who wants to keep his job has an incentive to make irreversible investments of corporate wealth in assets that are complementary to his own skills and abilities. They argue that to reduce the threat of replacement, managers who underperform their industry peers have more incentive to overpay for their acquisitions or to enter new businesses they might be good at. Shleifer and Vishny (1989) also argue that value-reducing diversification is more likely in firms that are underperforming their industry peers.

It is widely argued that there exist important systems in Japan that serve as mechanisms for internal and external governance, and that these mechanisms play an important role in mitigating the manager-shareholder conflict. A key aspect of Japanese corporate governance mechanisms is that some firms maintain close financial ties with commercial banks and receive substantial debt and/or equity financing from them. As Jensen (1986) argues, the fixed-payment pattern of this large debt can create an incentive for managers to overcome their inefficiencies. Furthermore, Fama (1990) argues that loans allow the monitoring of the conflict between debtholders and shareholders to be largely delegated to banks and provide mechanisms for monitoring this conflict.

In addition to corporate lending, Japanese banks are allowed to own up to 5 percent of a firm's equity. In general, Japanese banks hold a substantial portion of voting rights in many firms. In 1990, Japanese financial institutions, including banks and insurance companies, held $46.0 \%$ of the shares listed on all the eight stock exchanges in Japan [Tokyo Stock Exchange Fact Book, 1993]. Since large shareholders tend to receive more benefits from monitoring, Japanese 
financial institutions as large shareholders are expected to undertake an important monitoring role in reducing managerial inefficiencies [Shleifer and Vishny (1986) and Jensen (1989)]. ${ }^{5}$ To see the role of Japanese governance systems in the market for corporate control, we examine the effect of bidding firms' capital and ownership structure on the stock-price reaction to the announcement of mergers.

Our evidence suggests that Japanese mergers are, on average, value-increasing events for shareholders of acquiring firms. We find that shareholders of acquiring firms realize a positive two-day announcement return of $1.41 \%$, which is significant at the 0.01 level. Consistent with the findings of Morck, Shleifer, and Vishny (1990), we find that bidder returns are higher when the bidders acquire firms operating in the same industry, or when the bidders performed well prior to the merger. We also find that bidder returns are most striking when bidders with strong past stock return performances acquire targets in the same industries. For this type of merger, bidder returns are $3.50 \%$ on average and significantly higher than for any other types of mergers. In contrast, bidders with bad performance that acquire targets in different industries realize the smallest return -- an insignificant average return of $0.02 \%$. Thus, our evidence suggests that firm value is affected by managerial discretion in making acquisitions. We also find that unlike non-keiretsu firms, returns to keiretsu firms are higher when they acquire firms operating in different industries, supporting the view that the stock market differentiates unrelated acquisitions by keiretsu firm from those by non-keiretsu firms.

We also find that Japanese corporate control mechanisms perform an important role in monitoring managers. We find a positive and significant relation between leverage and abnormal returns to acquiring firms. This positive relation is more pronounced when the level of loans the bidder utilized from financial institutions is used in place of total debt to measure the leverage ratio, suggesting that the control function of debt in Japan comes mainly from loans. These findings are consistent with Jensen's (1986) claim that debt controls managerial discretion. The evidence also

\footnotetext{
5 Japanese corporate investors also hold extensive equity in other corporations. In 1990, equity ownership held by corporate shareholders was, on average, $24.8 \%$ of the shares listed on all the eight stock exchanges in Japan.
} 
lends support to Fama's (1990) argument by implying that loans reduce the agency costs of debt and induce managers to follow a value-maximizing policy.

Overall, our results provide evidence that in mergers where the manager's private benefits are likely to be smallest or in mergers where the influence of internal corporate governance is likely to be greatest, there is a statistically and economically significant increase in firm value. In contrast, other types of mergers do not display any evidence of an increase in firm value.

The remainder of the paper proceeds as follows. In section I, we review the related literature. Section II describes the data. In section III, we provide abnormal returns for various subsamples of interest and report results from cross-sectional regressions. A summary and concluding remarks are presented in section IV.

\section{A review of the literature}

Our paper is closely related to work by Pettway and Yamada (1986), who examine bidder and target returns in Japanese mergers. Pettway and Yamada (1986) show that for their sample of 50 Japanese bidders during the period 1977-1984, bidder returns are significantly positive around merger announcements. However, their study uses the board-meeting date, which is usually the resolution date, as the announcement date. Consequently, their evidence is not directly comparable to American evidence, which uses the first public announcement date. We find several cases, in fact, where the first public announcement dates from Japanese daily newspapers are substantially ahead of the board-meeting dates, sometimes by as much as three years. Furthermore, their study does not examine issues related to the cross-sectional variation in bidder returns.

In related work, Kang (1993), using announcements in the Wall Street Journal, finds that Japanese bidders acquiring U.S. firms experience a significant positive 2-day announcement abnormal return of $0.59 \%$. Using a sample of 119 Japanese bidding firms from 1975 to 1988 , he shows that bidder-specific characteristics are useful in explaining the cross-sectional variation in bidder returns: Returns to Japanese bidders increase with the bidder's leverage and the bidder's ties to financial institutions through borrowings. He interprets these results as evidence that debt 
controls managerial discretion and performs an important monitoring role. While his study has the advantage of using the announcement date identified from the Wall Street Journal, it focuses only on cross-border acquisitions, where Japanese bidder returns can be affected by several other factors, such as the exchange-rate movement, the anticipated U.S. trade restriction, the size of the U.S. market, and its political stability.

Our paper is also related to several other studies that examine the link between the corporate control mechanisms in Japan and firm performance. ${ }^{6}$ Hoshi, Kashyap, and Scharfstein (1991) provide evidence that investment by Japanese firms is affected by their financial structure. They find that for firms with a close relationship to a bank, liquidity does not play a role in determining investment whereas Tobin's $\mathrm{Q}$ has a major role, and for firms that do not maintain such a relationship, the opposite results are obtained. Given that bank-affiliated firms can avoid armslength capital-market transactions in financing investments, Hoshi, Kashyap, and Scharfstein (1991) interpret these results as evidence that bank-affiliated firms can circumvent Jensen and Meckling's (1976) incentive problem and Myers and Majluf's (1984) asymmetric information problem. Prowse (1990) also finds that a close financial tie with large banks reduces the agency costs in a firm's financial structure and thus influences its investment decisions.

Evidence on the role of ownership structure in Japan is provided by Prowse (1992), Lichtenberg and Pushner (1994) and Kang and Shivdasani (1996). Prowse (1992) shows no significant relationship between ownership concentration and accounting profit rate for a sample of 734 Japanese firms. Lichtenberg and Pushner (1994) find that equity ownership by financial institutions has a positive effect on corporate performance in Japan while equity ownership by other corporations has a negative effect. In comparison, Kang and Shivdasani (1996) show that corporate shareholders play an important role during outside succession. Using a sample of 432 Japanese firms that announce top management turnover during 1985 to 1990, they document that the likelihood of an outside appointment increases significantly with the ownership by corporate investors. The stock-price reaction, however, is not related to the ownership by corporate

\footnotetext{
${ }^{6}$ See Jensen and Warner (1988) for evidence on this issue in the U.S.
} 
investors. They also find that outside succession is more likely when the removal of the old president is forced, and the stock-price reaction is significantly positive when turnover is forced and the successor is appointed from outside the firm. They suggest that the disciplinary decisions of Japanese governance mechanisms are consistent with shareholder wealth maximization.

\section{Data}

Our sample consists of non-financial Japanese acquiring firms that are listed on either the First Section or the Second Section of the Tokyo Stock Exchange (TSE). Initially, we identified a sample of acquiring firms from the Shohou (Gazette) published by the TSE, in which the effective date of the merger is between March 31, 1977 and December 1, 1990. We then eliminate those cases where merging firms owned all the shares of the acquired firm prior to the merger. This procedure yields a sample of 132 acquiring firms. For these 132 acquiring firms, we identify the initial public announcement date of the merger from four daily newspapers published by Nihon Keizai Shimbun-sha: Nihon Keizai Shimbun (Nikkei Economic Journal) which is the equivalent of the Wall Street Journal for Japan, Nikkei Sangyo Shimbun (Industrial Journal), Nikkei Ryutuu Shimbun (Distribution Journal), and Nikkei Kinyuu Shimbun (Finance Journal). The date that a merger announcement first appears in any one of these four publications is used as the announcement date. Finally, we confine our sample to acquiring firms for which stock-price data are available on the daily return file from the Pacific-Basin Capital Markets (PACAP) Research Center. These restrictions result in a final sample of 104 observations. ${ }^{7}$ Sixty-four firms financed the entire transaction through an exchange of common stock, and forty firms used the combination of common stock and cash as the form of payment when they acquired targets.

\footnotetext{
7 In many cases, the acquired firms were not listed on the TSE at the time of merger announcement. We find that for the targets of the 104 bidders, only 17 target firms were listed on the TSE, while two target firms were listed on the regional stock exchanges, Nagoya and Osaka, with the remaining 85 targets held privately. Kester (1991) also shows that most Japanese merger and acquisition activity has been concentrated in the third tier of the market, where targets are small and unlisted. Since the PACAP file does not cover delisted firms due to mergers during our sample period, we restrict our analysis only to bidders.
} 
Table I summarizes Japanese merger activity by year and by industry of acquiring firms. Years 1989, 1988, and 1985 experience the most merger announcements with 14, 12, and 11 cases, respectively. A breakdown of mergers by industry shows that most acquiring firms are classified as manufacturing (69 cases), wholesale and retail (20 cases), and construction (8 cases).

Table II shows summary statistics for a sample of 104 Japanese acquiring firms. These data are obtained from the PACAP Research Center database, Nikkei database, Analyst's Guide by Daiwa Institutes of Research Ltd., Shohou by the TSE, Annual Securities Statistics by the TSE, and acquiring firms' annual/semi-annual reports. Panel A reports the merger-specific characteristics and the past stock return performance for sample firms. Using the 3-digit SIC codes provided by the PACAP, we find that $55 \%$ of our sample firms acquired target firms operating in the same industry. ${ }^{8}$ The median (mean) relative book value of target equity to bidder equity is $14 \%(32 \%)$ and the median (mean) ratio of the value of transaction to market value of bidder equity is $7 \%(17 \%)$, where the value of the transaction is the sum of cash and common stock paid to the target. Common stock paid is measured by the number of acquiring firm's shares issued to target times the acquiring firm's stock price per share at the end of the fiscal year preceding the merger announcement. For the calculation of the value of the transaction, target shares held by the bidder are excluded from the number of shares outstanding to avoid double counting. Panel A also shows that Japanese acquiring firms hold a relatively large fraction of target shares before the merger announcement (median 20\% and mean 27\%). ${ }^{9}$ To measure the past performance of the acquiring firm, we use the firm's cumulative excess stock return relative to its industry. We compute the industry-adjusted cumulative excess stock return from -270 days to -20 days before the merger announcement using the value-weighted Tokyo Stock Price Index (TOPIX)

\footnotetext{
${ }^{8}$ We refer to a merger involving two firms engaged in the same industry as a related merger and a merger involving two firms engaged in different industries as an unrelated merger.

9 The Japanese Ministry of Finance classifies a firm as a "subsidiary" (ko-gaisha) if more than 50 percent of its shares are owned by the other firm and classifies a firm as a "related" firm (kanren-gaisha) if more than 20 percent but less than 50 percent are owned by the other firm. See Ballon and Tomita (1988).
} 
for each industry. The mean and median industry-adjusted returns during the previous one-year period are $8.75 \%$ and $4.50 \%$, respectively, and they are statistically significant.

Panel B of table II shows summary statistics of firm-specific and governance characteristics for our sample firms. The market value of bidder equity averages $¥ 173$ billion, and the mean book value of assets is $¥ 274$ billion. The average price-earnings ratio for Japanese sample firms is 68 times, which is relatively high compared to U.S. standards [French and Poterba (1991)]. Leverage is measured by debt divided by the quasi-market value of the firm (debt plus market value of equity) and is, on average, 55\%. Loans from financial institutions represent about $44 \%$ of this leverage ratio.

Panel B also presents the equity ownership structure of Japanese acquiring firms. Japanese financial institutions including banks and insurance companies and other corporations hold, on average, $31 \%$ and $30 \%$ of a firm's equity, respectively, whereas the top ten shareholders and managers who are the members of the boards of directors own $46 \%$ and $4 \%$ of the equity, respectively. In panel $\mathrm{B}$, we divide the sample into firms that belong to a keiretsu and those that do not. We use the 1985 edition of Industrial Groupings in Japan by Dodwell Marketing Consultants to determine each firm's keiretsu affiliation. We focus on the bank-oriented keiretsu and consider firms to be belonging to a keiretsu if they are a member of any one of the following groups: Mitsubishi, Mitsui, Sumitomo, DKB, Fuyo, or Sanwa. According to this classification, $40 \%$ of our sample firms belong to a keiretsu.

\section{Empirical results}

\section{A. Abnormal returns}

Abnormal returns are computed in the following way. We first group TSE securities into ten control portfolios ranked according to their Scholes and Williams (1977) beta estimates computed with respect to the PACAP equally-weighted portfolio for Japan. Then, we assign each acquiring firm to the control portfolio that corresponds to the beta decile of the acquiring firm. We compute the abnormal return on a particular day by taking the difference between the return on the 
acquiring firm's shares and the return on the equally-weighted control portfolio assigned to the firm. This daily abnormal return is compounded to get the cumulative abnormal return (CAR) from day $t_{1}$ before the merger announcement date to day $t_{2}$ after the merger announcement date. We use t-statistics to test the hypothesis that the average CARs are equal to zero and sign-rank test statistics to test the hypothesis that the CARs are distributed symmetrically around zero. We obtain similar results when we use the market model method to estimate the abnormal returns.

Table III reports the mean and median CARs for 104 Japanese acquiring firms around the announcement date $(\mathrm{AD})$ and the effective date $(\mathrm{ED})$ of mergers. The mean CAR (AD-1, $A D)$ is $1.41 \%$ and the mean CAR (AD-1, $\mathrm{AD}+1)$ is $1.19 \%$, which are significant at the 0.01 and 0.05 levels, respectively. The sign-rank test also indicates that the median CAR (AD-1, AD) is significantly different from zero at the 0.05 level. Our results for Japanese bidder returns around the announcement date contrast with those for the U.S. bidders. Considerable evidence in the U.S. [Jensen and Ruback (1983)] suggests that bidder returns in friendly acquisitions are at best close to zero and sometimes significantly negative. ${ }^{10}$ Table III also shows that the CAR from one day after the announcement to one day before the merger effective date (AD+1, ED-1) is insignificantly negative. Further, the CAR for the two-day window surrounding the merger effective date (ED-1, ED) is insignificantly positive, which is consistent with evidence for the U.S. [Vijh (1994)]. Finally, table III indicates that both the mean and median CARs from sixty days before the announcement to twenty days after the effective date (AD-60, ED+20) are insignificantly negative.

10 One possible explanation for positive bidder returns in Japanese mergers is that many Japanese bidders may acquire targets at discount from their true values since most of targets in our sample are unlisted. To this effect, we compare the abnormal returns for bidders whose targets are listed with those for bidders whose targets are unlisted. Consistent with this view, we find that the mean and median returns are significant only for bidders whose targets are unlisted (the mean of $1.48 \%$ and the median of $0.52 \%$ ). Unfortunately, the mean and median differences between the two sets of bidders are not significant. Alternatively, a positive bidder return may be largely due to the "bubble economy" in Japan during the second half of the 1980s. Our evidence, however, suggests that the stock-price reaction associated with merger announcements is significantly positive only for the mergers before 1986 . Hence, the bubble economy explanation for the positive bidder return does not appear to hold for our sample. Finally, given that most of targets in our sample are small and unlisted, it is unlikely that positive bidder returns come from the creation of monopoly power. 


\section{B. Do managerial incentives matter?}

In this section, we examine whether the announcement effect documented in section III.A is associated with the potential differences in managerial objectives in Japanese mergers.

Table IV provides the CARs (AD-1, AD) for various subsamples stratified by mergerspecific characteristics and past stock return performance for the sample of 104 acquiring firms. These classifications are intended to capture the potential differences in managerial incentives in mergers. Panel A of table IV separates firms into those involved in a related acquisition and those involved in an unrelated acquisition. The results in panel A show that when bidding firms pursue related acquisitions, the mean CAR is $2.28 \%$ and the median CAR is $0.74 \%$. These are significant at the 0.01 and 0.05 levels, respectively. On the other hand, in an unrelated acquisitionin, the mean and median bidder CARs are only $0.36 \%$ and $0.00 \%$, respectively, both of which are not statistically significant at the conventional levels. The mean difference between these two subsamples is a statistically significant $1.92 \%$ with a t-statistic of 1.90 .

Panel B of table IV reports the results for subsamples based on the bidder's past industryadjusted stock return performance. We find that bidders whose stock price performance has been above average relative to their industries realize a positive mean CAR of $2.07 \%(\mathrm{t}=2.67)$. In comparison, for the subsample where bidders underperform their industries, the average CAR is $0.43 \%$, and statistically insignificant. The mean return difference of $1.64 \%$ is again significant at the 0.10 level.

Taken together, these results are generally consistent with those of Morck, Shleifer, and Vishny (1990), who perform a similar analysis for a sample of 326 U.S. mergers, and support the view that managerial incentives affect a firm's investment decisions, and therefore firm value. The results in panel B also suggest that a potential source of takeover gains depends, at least partly, on the quality of the bidding firm's management and its ability to reallocate target resources in an efficient way.

In panels $\mathrm{C}$ and $\mathrm{D}$ of table IV, we report the CARs, stratified according to the median relative size of the target and the bidder. As a measure of relative size, we use the ratio of the book 
value of target equity to the book value of bidder equity in panel $\mathrm{C}$, and the ratio of the value of the transaction to the market value of bidder equity in panel D. If the bidding manager's major incentive for acquisition is to realize synergy effect by increasing economies of scale, then a larger size target, which is more likely to produce such an effect, will be associated with a higher return to the bidder. ${ }^{11}$ Alternatively, if a larger target implies the bidding managers' desire to expand their firm beyond the optimal size to increase resources under their control [Jensen (1986)], then a negative relation between the size of the target and the return to the bidder will result. For the subsample where the relative size measured by the book value is greater than the sample median (panel C), the average bidder CAR is $2.14 \%$, which is significant at the 0.05 level. In comparison, for the subsample where the relative size measured by the book value is smaller than the sample median, the average bidder CAR is $0.67 \%$ and not significant. This pattern is more pronounced when the value of the transaction is used as a measure of the target's relative size (panel D). The average bidder CAR in the subsample above the sample median is $2.51 \%$ with a tstatistic of 2.79 and that in the subsample below the sample median is $0.32 \%$ with a t-statistic of 0.62. The mean difference of $2.19 \%$ is statistically significant at the 0.05 level.

The results in table IV suggest that the relatedness of acquisitions and the past stock return performance of the bidder play an important role in explaining the return realized by shareholders of Japanese bidders. To further examine the relation between managerial objectives and bidder returns, we split the sample into four groups according to the relatedness of acquisitions and the past stock return performance of the bidder: Related/bad performance, related/good performance, unrelated/bad performance, and unrelated/good performance. Results in table $\mathrm{V}$ show that shareholders of bidders characterized by the "related/good performance" mergers realize the largest positive return. The mean and median CAR are $3.50 \%$ and $1.67 \%$, respectively, and both of them are statistically significant. On the other hand, shareholders of bidders in other types of mergers

11 Asquith, Bruner, and Mullins (1983) hypothesize that if the bidding firm's value is affected by a merger, the observed abnormal return should be related to the relative size of the bidding and target firms. They indeed find that the bidder's abnormal return is positively related to the relative size of the merger partners. 
earn statistically insignificant returns. For example, shareholders of bidders in the "unrelated/bad performance" mergers realize the smallest mean return of $0.02 \%$ with a median of $0.00 \%$. Furthermore, the differences in mean returns between the "related/good performance" group and each of the other three groups are all statistically significant at the conventional levels. This provides further evidence that significant positive abnormal returns for Japanese bidders are limited to a specific subset of the sample and that the Japanese stock market reacts favorably only to mergers where managerial incentives are most closely aligned with shareholder interests.

\section{Bidder returns and Japanese corporate governance mechanisms}

The literature on the market for corporate control also suggests that bidder returns are related to firm-specific governance characteristics which serve as mechanisms to control managerial discretion. According to Jensen (1986), managers endowed with free cash flow tend to invest it in negative-NPV projects rather than pay it out to shareholders, and large debt creation helps limit the waste of the free cash flow and controls managerial discretion. This suggests that Japanese bidders who maintain high leverage are less likely to undertake value-decreasing acquisitions, and thus the stock market reaction to merger announcements is more likely to be positive for highly levered bidders. Fama (1990) also argues that bank loans provide a mechanism for monitoring the conflict between debtholders and shareholders and reduce managerial discretion. To evaluate the role of these capital structure variables in Japanese mergers, we further divide the sample into two subgroups according to the median leverage ratio (total debt / market value of the firm) and the median loan ratio (loans from financial institutions / market value of the firm).

The evidence in panel A of table VI indicates that Japanese bidders with leverage ratios above the sample median experience positive mean and median CARs of $1.75 \%$ and $0.83 \%$, respectively, both of which are significant at the 0.01 levels, while those with leverage ratios below the sample median realize insignificant mean and median CARs of $1.07 \%$ and $-0.18 \%$, respectively. The return differences, however, lack statistical significance. Results are much more striking when loans are used for classification. Results in panel B show that firms with loan 
ratios above the sample median have an average two-day abnormal return associated with the announcement of mergers of $2.74 \%$, which is significantly larger than the abnormal return of $0.07 \%$ for firms with loan ratios below the sample median (at the 0.01 level). These results support both Jensen's (1986) free cash flow hypothesis and Fama's (1990) monitoring hypothesis, and suggest that debt, loans in particular, plays an important governance role in controlling Japanese managerial discretion. The results are also consistent with those of Kang (1993), who finds that returns to Japanese bidders acquiring U.S firms are positively related to the bidder's leverage and the bidder's ties to financial institutions through borrowings, and those of Kang and Stulz (1996), who show that the announcement return of equity issues in Japan increase with the loan component of a firm's capital structure.

The concentrated equity ownership by large shareholders can provide strong incentives for them to monitor the performance of management and to reduce managerial discretion [Shleifer and Vishny (1986) and Jensen (1989)]. To investigate the role of blockholders in Japan and their effects on firm value, we again bifurcate our sample by equity ownership held by the ten largest shareholders. Consistent with the monitoring role of large shareholders, panel C of table VI shows that only firms with equity ownership by the top ten shareholders above the sample median have a significant average return of $1.48 \%(\mathrm{t}=2.19)$. The difference in mean returns between the two groups of firms, however, is not significant.

In panel $\mathrm{D}$, we divide our sample into firms that belong to keiretsu and those that do not. If the management of keiretsu firms behaves differently and pursues different goals from the management of non-keiretsu firms, we expect the announcement returns to be different between the two groups. The evidence in panel D indicates that while mean returns are significant for both groups, median returns are significant only for keiretsu firms.

If managers in keiretsu firms are concerned about other keiretsu members and acquire targets to maximize the aggregate value of the whole keiretsu network [Kester (1991)], then unrelated diversification pursued by managers in keiretsu firms will have a different effect on firm value compared to unrelated diversification pursued by managers in non-keiretsu firms. To 
examine this issue further, in table VII, we divide our sample into four groups: Related acquisitions by keiretsu firms, unrelated acquisitions by keiretsu firms, related acquisitions by nonkeiretsu firms, and unrelated acquisitions by non-keiretsu firms. The most important finding of table VII is that for keiretsu firms, unrelated acquisitions lead to a significant positive two-day announcement return. The mean CAR for unrelated acquisitions by keiretsu firms is $1.90 \%$ and the median is $1.13 \%$, which are significant at the 0.05 and 0.01 levels, respectively. The corresponding mean and median returns for related acquisitions by keiretsu firms are $0.84 \%$ and $-0.02 \%$, respectively, and are not statistically significant. We find an opposite pattern for nonkeiretsu firms. The mean (median) CAR for unrelated acquisitions by non-keiretsu firms is an insignificant $-1.12 \%(-0.69 \%)$, compared to a significant $2.99 \%(0.81 \%)$ for related acquisitions by non-keiretsu firms. ${ }^{12}$ Therefore, our results support Kester's (1991) argument that Japanese managers in group-affiliated firms have a strong incentive to maximize value among keiretsu member firms, and the stock market reacts positively when managers pursue this goal by acquiring firms in different industries. ${ }^{13}$

\section{Cross-sectional regression analysis}

For the cross-sectional analysis, we use the CAR (AD-1, AD) as the dependent variable. Table VIII reports regression estimates for our sample of 104 Japanese bidders. The first

\footnotetext{
12 In unreported tests, we estimate the keiretsu-industry effect in a regression of the CAR (AD-1, AD) on a dummy variable that takes the value of one for a related acquisition by keiretsu firms, a dummy variable that takes the value of one for an unrelated acquisition by keiretsu firms, a dummy variable that takes the value of one for a related acquisition by non-keiretsu firms, and target equity ownership held by bidders prior to the merger announcement. The regression results lead to similar conclusions: Returns for both unrelated acquisitions by keiretsu firms and related acquisitions by non-keiretsu firms are significantly higher than those for unrelated acquisitions by nonkeiretsu firms.
}

${ }^{13}$ Since alternative Keiretsu classifications lead to very different lists of member firms [Saxonhouse (1993)], we also estimate our tests using a broader definition of keiretsu membership, which includes all types of keiretsu in Japan, and find that results are qualitatively the same as those reported in table VII. Specifically, the mean and median CARs for unrelated acquisitions by all types of keiretsu firms are $1.78 \%$ and $0.74 \%$, respectively, both of which are significant at the 0.01 level, and those for related acquisitions by all types of keiretsu firms are $0.70 \%$ and $-0.12 \%$, respectively, and are not statistically significant. On the other hand, the mean and median CAR for unrelated acquisitions by non-keiretsu firms are $-1.93 \%$ and $-1.29 \%$, respectively, both of which are significant at the 0.10 level, and those for related acquisitions by non-keiretsu firms are $3.50 \%$ and $1.27 \%$, respectively, both of which are significant at the 0.05 level. 
regression includes only merger-specific characteristics and the past performance of the bidder as explanatory variables. These include the dummy variable for the relatedness of acquisition between the bidder and the target using 3-digit SIC codes, the past stock-return performance of the bidder, the ratio of the value of transaction to market value of bidder equity, and target equity ownership held by the bidder prior to the merger announcement. ${ }^{14}$ The results show that bidder returns are positively related to the past stock-return performance of the bidder $(t=2.53)$ and to the relative size of the target to the bidder $(\mathrm{t}=1.85)$. These findings confirm our previous univariate test results and are consistent with the view that merger benefits to shareholders of bidding firms are related to the objective functions of bidding firms' managers. The dummy variable for the relatedness of acquisitions, however, is not statistically significant. Our result for the positive relation between the bidder return and the past stock-return performance of the bidder seems inconsistent with Roll's (1986) hubris hypothesis. This is because the managers who are more likely to be infected with hubris are those of firms that have performed well, and accordingly, the hubris hypothesis predicts that those managers are more likely to overpay for their targets. Our evidence, therefore, is difficult to square with the hubris hypothesis.

In the second regression, we replace a dummy variable for the relatedness of acquisition and the variable for the bidder's past performance by a dummy variable that takes the value of one if the bidder acquires a target in the same industry and the previous bidder industry-adjusted stock return is positive. This dummy variable is intended to proxy for mergers where bidding managers' incentives are most closely aligned with those of shareholders. Regression (2) shows that related acquisitions by good managers lead to significantly higher returns than other types of mergers. All else being equal, the return from a related merger by good managers is $2.88 \%(t=2.54)$ higher than the return from other types of mergers.

In regressions (3) and (4), we use only firm-specific governance characteristics as explanatory variables. These results indicate that both the leverage ratio and the loan ratio are

\footnotetext{
14 Mikkelson and Ruback (1985) show that prior bidder ownership of target equity affects bidder returns.
} 
statistically significant variables in explaining the cross-sectional variation in bidder returns. The other governance variables, however, including equity ownership held by the top ten shareholders, are not statistically significant. When we estimate the regression using all explanatory variables [regression (5)], our results remain the same.

To gain further insight into the role of ownership structure in Japanese bidding firms, we replace blockownership held by the top ten shareholders in regression (5) by equity ownership held by corporate shareholders and equity ownership held by financial institutions, and add management equity ownership. Jensen and Meckling (1976) argue that increased management equity ownership can lead to a better alignment of shareholder and management interests. They argue that as management equity ownership increases, the manager's incentive to exploit outside shareholders decreases, and hence the manager is less likely to undertake actions that reduce shareholder wealth. This suggests that bidder returns are higher when management equity ownership is larger. The estimates are reported in regression (6). A negative and significant coefficient on equity ownership by corporate shareholders $(t=-2.10)$ is inconsistent with the view that Japanese corporate shareholders play an important monitoring role as large shareholders. ${ }^{15}$ One possible explanation for this negative relation between bidder returns and equity ownership by corporate shareholders is that concentrated equity ownership by large corporate shareholders allows them to receive private benefits that do not accrue to other shareholders, thereby decreasing firm value [Barclay and Holderness (1989) and Barclay, Holderness, and Pontiff (1993)]. It is also possible that, as argued by Lichtenberg and Pushner (1994), a high level of equity ownership by corporate shareholders insulates managers from external influences and therefore leaves them

15 Firms in a keiretsu typically own substantial equity in other keiretsu member firms. This mutual share ownership implies that the effect of corporate ownership in a keiretsu may be different from that in a non-keiretsu. To examine the keiretsu-mutual ownership effect, we estimate regression (6) using an additional interaction variable, equity ownership by corporate shareholders times keiretsu dummy. For this specification, the regression coefficient on equity ownership by corporate shareholders is -0.0009 with a t-statistic of -2.37 . On the other hand, the regression coefficient on the interaction variable is 0.0003 with a t-statistic of 0.81 . Therefore, equity ownership by corporate shareholders matters for both keiretsu and non-keiretsu firms. 
free of the discipline. Regression (6) also shows negative coefficients on equity ownership by financial institutions and managers, but they are not significant. ${ }^{16}$

Stulz (1988), however, argues that firm value first increases and then decreases when management equity ownership increases. He suggests that when management equity ownership is small, managerial interests are more likely to be allied with shareholders'. However, when management equity ownership is large enough to give managers control, an increase in managerial ownership makes managers more entrenched. Therefore, his model implies that there is a nonmonotonic relation between returns to bidding firms and management equity ownership. Morck, Shleifer and Vishny (1988) and McConnell and Servaes $(1990,1995)$ show that there is a nonmonotonic relation between market valuation and management equity ownership.

To investigate whether there exists a nonmonotonic effect of the management equity ownership on the market value of the bidder's equity, we run a piecewise linear regression with turning points of $5 \%, 10 \%, 15 \%$, and $20 \%$, and report the result in regression (7) of table VIII. Results indicate that bidder returns increase significantly as management equity ownership increases from $15 \%$ to $20 \%$. Management equity ownership for other turning points, however, is not statistically significant.

As a further check, we perform one sensitivity test on our management ownership measure. Instead of using a piecewise linear regression with several turning points, we analyze a nonmonotonic relation between bidder return and management equity ownership, employing two independent variables, management equity ownership and management equity ownership squared. In this specification, the coefficient for management equity ownership is 0.0024 (p-value $=0.19$ ) and the coefficient for management equity ownership squared is -0.0001 ( $\mathrm{p}$-value $=0.11$ ).

16 We reestimate regressions (1) through (6) using an additional dummy variable that takes the value of one if bidders use a combination of cash and common stock as the form of payment and zero if bidders use only common stock. Asquith, Bruner and Mullins (1987) and Travlos (1987) suggest that the proposed method of financing affects bidder returns. They argue that stock financing tends to release adverse information about the acquiring firms [Myers and Majluf (1984)] and find that bidder returns are negative in pure stock exchange cases. Our results show that the coefficients on this variable are statistically indistinguishable from zero. 
Overall, these results indicate that in the cases of Japanese mergers, the effect of management equity ownership on bidder returns is not significant. One potential explanation for the lack of a significant relation between bidder returns and management equity ownership is that equity ownership by Japanese managers is considerably less than equity ownership by American managers. ${ }^{17}$ Accordingly, management equity ownership in Japan may not play an important role as an incentive control mechanism. ${ }^{18}$

\section{Summary and conclusions}

We provide evidence that mergers in Japan result in significantly positive wealth gains to shareholders of bidding firms. Returns to shareholders of bidding firms are significantly higher when firms acquire targets operating in the same industry, when their managers performed well prior to the merger, and when their managers acquire relatively large targets. We also find that the cross-sectional variation in bidder returns is related to a bidding firm's capital structure, which serves as a mechanism to control management discretion: Returns to shareholders of bidding firms increase with the bidder's leverage ratio and the bidder's loan ratio. Our results are generally consistent with the view that managerial incentives affect a firm's investment decision and therefore firm value, and that these incentives are affected by the internal corporate governance mechanisms that control managerial discretion. Finally, our finding that returns for unrelated acquisitions by

17 For example, Morck, Shleifer, and Vishny (1988) show that for a sample of Fortune 500 firms, the mean (median) equity ownership by directors on the board is 10.6\% (3.4\%) in 1980. McConnell and Servaes (1990) report that in 1976 and 1986 the mean (median) board ownership for a sample of more than 1000 firm listed on the New York Stock Exchange or American Stock Exchange is $11.8 \%$ (5.05\%). The corresponding numbers for our Japanese sample firms are the mean of $4 \%$ and the median of $1 \%$, respectively.

18 While we do not report the results in table VIII, we estimate regression (7) separately for two subperiods: 19761983 and 1984-1990. Jensen (1989), Kester (1991), and Hoshi, Kashyap, and Scharfstein (1993) argue that the deregulation of the Japanese domestic bond market, the easy access to the global capital markets, and the large cash balance held by Japanese firms in recent years have allowed Japanese firms to reduce their reliance on bank debt and to become less dependent on their banks. Given this financial shift, it is possible that the monitoring role of Japanese banks has diminished over time and thus may be less active in the later period than in the earlier period. The regression result shows that the coefficient on the loan ratio is significantly positive only in the earlier period, supporting the view that the monitoring role of Japanese banks has weakened over time. The average CAR (AD-1, AD) for Japanese bidders in the 1976-1983 period is $2.00 \%$ with a t-statistic of 2.11 while the average CAR (AD-1, $\mathrm{AD}$ ) in the $1984-1990$ period is $0.94 \%$ with a t-statistic of 1.63 . The CARs for the two subperiods, however, are not significantly different. 
keiretsu firms are significantly positive supports the view that the stock market perceives unrelated acquisitions by keiretsu firms to be different from those by non-keiretsu firms. Overall, these results provide evidence on incentives faced by Japanese managers, the working of the Japanese market for corporate control, and the functioning of corporate control mechanisms in Japan. 


\section{References}

Amihud, Yakov and Baruch Lev, 1981, Risk reduction as a managerial motive for conglomerate mergers, Bell Journal of Economics 12, 605-617.

Aoki, Masahiko, 1984, Aspects of the Japanese firm, in: Masahiko Aoki, ed., The economic analysis of the Japanese firm (North-Holland, Amsterdam) 3-43.

Aoki, Masahiko, 1990, Toward an economic model of the Japanese firm, Journal of Economic Literature 28, 1-27.

Asquith, Paul, Robert F. Bruner, and David W. Mullins Jr., 1983, The gains to bidding firms from merger, Journal of Financial Economics 11, 121-139.

Asquith, Paul, Robert F. Bruner, and David W. Mullins Jr., 1987, Merger returns and the form of financing, working paper, Harvard University (MA, Boston).

Ballon, Robert J. and Iwao Tomita, 1988, The financial behavior of Japanese corporations, Kodansha International, New York.

Barclay, Michael J. and Clifford G. Holderness, 1989, Private benefits from control of corporations, Journal of Financial Economics 25, 371-395.

Barclay, Michael J., Clifford G. Holderness, and Jeffrey Pontiff, 1993, Private benefits from blockownership and discounts on closed-end funds, Journal of Financial Economics 23, 263-291.

Berger, Philip G. and Eli Ofek, 1994, Bustup takeovers of value destroying diversified firms, working paper, University of Pennsylvania (PA, Philadelphia).

Berglof, Erik and Enrico Perotti, 1994, The governance structure of the Japanese financial keiretsu, Journal of Financial Economics 36, 259-284.

Byrd, John W. and Kent A. Hickman, 1992, Do outside directors monitor managers? Evidence from tender offer bids, Journal of Financial Economics 32, 195-221.

Comment, Robert and Gregg A. Jarrell, 1995, Corporate focus and stock returns, Journal of Financial Economics 37, 67-87.

Fama, Eugene F., 1990, Contract costs and financing decisions, Journal of Business 63, 71-91.

French, Kenneth R. and James M. Poterba, 1991, Were Japanese stock prices too high? Journal of Financial Economics 29, 337-364.

Hoshi, Takeo, Anil Kashyap, and David Scharfstein, 1991, Corporate structure, liquidity and investment: Evidence from Japanese industrial groups, Quarterly Journal of Economics $106,33-60$.

Hoshi, Takeo, Anil Kashyap, and David Scharfstein, 1994, The choice between public and private debt: An analysis of post-deregulation corporate financing in Japan, working paper, National Bureau of Economic Research. 
Jarrell, Gregg A., James A. Brickley, and Jeffry M. Netter, 1988, The market for corporate control: The empirical evidence since 1980, Journal of Economic Perspectives 2, 49-68.

Jensen, Michael C., 1986, Agency costs of free cash flows, corporate finance, and takeovers, American Economic Review 76, 323-329.

Jensen, Michael C., 1989, Eclipse of the public corporation, Harvard Business Review, No. 5, 61-74.

Jensen, Michael C. and William H. Meckling, 1976, Theory of the firm: Managerial behavior, agency costs and ownership structure, Journal of Financial Economics 3, 305-360.

Jensen, Michael C. and Richard S. Ruback, 1983, The market for corporate control: The scientific evidence, Journal of Financial Economics 11, 5-50.

Jensen, Michael C. and Jerold B. Warner, 1988, The distribution of power among corporate managers, shareholders, and directors, Journal of Financial Economics 20, 3-24.

Kaplan, Steven N., 1994, Top executive rewards and firm performance: A comparison of Japan and the United States, Journal of Political Economy 102, 510-546.

Kang, Jun-Koo, 1993, The international market for corporate control: Mergers and acquisitions of U.S. firms by Japanese firms, Journal of Financial Economics 34, 345-372.

Kang, Jun-Koo and Anil Shivdasani, 1996, Does the Japanese governance system enhance shareholder wealth? Evidence from the stock-price effects of top management turnover, Review of Financial Studies, forthcoming.

Kang, Jun-Koo and Rene M. Stulz, 1996, How different is Japanese corporate finance? An investigation of the information content of new security issues, Review of Financial Studies, forthcoming.

Kester, W. Carl, 1986, Capital and ownership structure: A comparison of United States and Japanese manufacturing corporations, Financial Management, Spring, 5-16.

Kester, W. Carl, 1990, Governance, contracting, and investment horizons: A look at Japan and Germany, The Continental Bank Journal of Applied Corporate Finance 5, 29-41.

Kester, W. Carl, 1991, Japanese takeovers: The global contest for corporate control, (Harvard Business School Press, Boston, MA).

Lang, Larry, Rene M. Stulz and, Ralph A. Walkling, 1989, Tobin's q and the gains from successful tender offers, Journal of Financial Economics 24, 137-154.

Lang, Larry and Rene M. Stulz, 1994, Tobin's q, corporate diversification and firm performance, Journal of Political Economy 102, 1248-1280.

Lewellen, Wilbur, Claudio Loderer, and Ahron Rosenfeld, 1985, Merger decisions and executive stock ownership in acquiring firms, Journal of Accounting and Economics 7, 209-231.

Lichtenberg, Frank R. and George M. Pushner, 1994, Ownership structure and corporate performance in Japan, Japan and the World Economy 6, 239-261. 
McConnell, John J. and Henri Servaes, 1990, Additional evidence on equity ownership and corporate value, Journal of Financial Economics 27, 595-612.

McConnell, John J. and Henri Servaes, 1995, Equity ownership and the two faces of debt, Journal of Financial Economics 39, 131-157.

Maloney, Michael T., Robert E. McCormick, and Mark L. Mitchell, 1993, Managerial decision making and capital structure, Journal of Business 66, 189-217.

Mikkelson, Wayne H. and Richard S. Ruback, 1985, An empirical analysis of the interfirm equity investment process, Journal of Financial Economics 14, 523-553.

Morck, Randall, Andrei Shleifer, and Robert W. Vishny, 1988, Management ownership and market valuation: An empirical analysis, Journal of Financial Economics 20, 293-316.

Morck, Randall, Andrei Shleifer, and Robert W. Vishny, 1990, Do managerial objectives drive bad acquisitions, Journal of Finance 45, 31-48.

Myers, Stewart C. and Nicholas S. Majluf, 1984, Corporate financing and investment decisions when firms have information that investors do not have, Journal of Financial Economics $13,187-221$.

Nakatani, Iwao, 1984, The economic role of financial corporate grouping, in: Masahiko Aoki, ed., The economic analysis of the Japanese firm (North-Holland, Amsterdam) 227-258.

Pettway, Richard H. and Takeshi Yamada, 1986, Mergers in Japan and their impacts upon stockholders' wealth, Financial Management, Winter, 43-52.

Porter, Michael E., 1992, Capital choices: Changing the way America invests in industry, The Continental Bank Journal of Applied Corporate Finance 5, 4-16.

Prowse, Stephen D., 1990, Institutional investment patterns and corporate financial behavior in the United States and Japan, Journal of Financial Economics 27, 43-66.

Prowse, Stephen D., 1992, The structure of corporate ownership in Japan, Journal of Finance 47, 1121-1140.

Roll, R., 1986, The hubris hypothesis of corporate takeovers, Journal of Business, 197-216.

Saxonhouse, G. R., 1993, What does Japanese trade structure tell us about Japanese trade policy?, The Journal of Economic Perspectives 7, 21-44.

Scholes, Myron S. and J. Williams, 1977, Estimating betas from nonsynchronous data, Journal of Financial Economics 5, 309-328.

Sheard, Paul, 1989, The main bank system and corporate monitoring and control in Japan, Journal of Economic Behavior and Organization 11, 399-422.

Shleifer, Andrei and Robert W. Vishny, 1986, Large shareholders and corporate control, Journal of Political Economy 94, 461-488.

Shleifer, Andrei and Robert W. Vishny, 1989, Managerial entrenchment: The case of managerspecific investments, Journal of Financial Economics 25, 123-139. 
Stulz, Rene M., 1988, Managerial control of voting rights: Financial policies and the market for corporate control, Journal of Financial Economics 20, 25-54.

Travlos, Nickolaos G., 1987, Corporate takeover bids, method of payment, and bidding firms' stock returns, Journal of Finance 42, 943-963.

Vijh, Anand M., 1994, The spinoff and merger ex-date effects, Journal of Finance 49, 581-609. 
Table I

Japanese merger activity, stratified by year and by bidder industry

The sample consists of 104 Japanese bidders listed on the Tokyo Stock Exchange for which an effective date of the merger fell between March 31, 1977 and December 1, 1990 and an announcement date could be obtained from any of the four daily newspapers: the Nihon Keizai Shimbun, Nikkei Sangyo Shimbun, Nikkei Ryutuu Shimbun, or Nikkei Kinyuu Shimbun.

Industry

Fishery Wholesale Transportation

Year \& Mining Construction Manufacturing \& Retail \& Communication Others ${ }^{1}$ Total

\begin{tabular}{|c|c|c|c|c|c|c|c|}
\hline 1976 & 0 & 0 & 2 & 2 & 0 & 0 & 4 \\
\hline 1977 & 0 & 0 & 7 & 2 & 0 & 0 & 9 \\
\hline 1978 & 0 & 0 & 4 & 1 & 0 & 0 & 5 \\
\hline 1979 & 0 & 0 & 5 & 0 & 0 & 0 & 5 \\
\hline 1980 & 1 & 0 & 2 & 1 & 0 & 0 & 4 \\
\hline 1981 & 0 & 1 & 3 & 0 & 0 & 0 & 4 \\
\hline 1982 & 0 & 0 & 7 & 1 & 0 & 0 & 8 \\
\hline 1983 & 1 & 0 & 5 & 0 & 0 & 1 & 7 \\
\hline 1984 & 0 & 1 & 6 & 1 & 0 & 0 & 8 \\
\hline 1985 & 0 & 3 & 6 & 1 & 0 & 1 & 11 \\
\hline 1986 & 0 & 1 & 3 & 2 & 0 & 0 & 6 \\
\hline 1987 & 0 & 0 & 3 & 3 & 0 & 0 & 6 \\
\hline 1988 & 0 & 0 & 7 & 4 & 1 & 0 & 12 \\
\hline 1989 & 0 & 2 & 8 & 2 & 1 & 1 & 14 \\
\hline 1990 & 0 & 0 & 1 & 0 & 0 & 0 & 1 \\
\hline Total & 2 & 8 & 69 & 20 & 2 & 3 & 104 \\
\hline
\end{tabular}

1 Others include real estate, electric power and gas, and services. 
Table II

Summary statistics for Japanese bidders

The sample consists of 104 Japanese bidders listed on the Tokyo Stock Exchange for which an effective date of the merger fell between March 31, 1977 and December 1, 1990 and an announcement date could be obtained from any of the four daily newspapers: the Nihon Keizai Shimbun, Nikkei Sangyo Shimbun, Nikkei Ryutuu Shimbun, or Nikkei Kinyuu Shimbun.

\begin{tabular}{|c|c|c|c|}
\hline Variable & Mean & Median & Standard de \\
\hline \multicolumn{4}{|c|}{ Panel A: Merger-specific / performance variables } \\
\hline $\begin{array}{l}\text { Fraction of firms involved in } \\
\text { related mergers }\end{array}$ & 0.55 & n.a. & n.a. \\
\hline Target book equity / bidder book equity & 0.32 & 0.14 & 0.68 \\
\hline $\begin{array}{l}\text { Value of the transaction / } \\
\text { market value of bidder equity }\end{array}$ & 0.17 & 0.07 & 0.28 \\
\hline Value of transaction (millions of yen): & 12997 & 2555 & 43020 \\
\hline Cash paid & 32.18 & 0.00 & 109.32 \\
\hline Common stock paid ${ }^{b}$ & 12965 & 2555 & 42969 \\
\hline $\begin{array}{l}\text { Target equity ownership held by bidders } \\
\text { prior to the merger announcement }\end{array}$ & 0.27 & 0.20 & 0.28 \\
\hline $\begin{array}{l}\text { Excess return over industry }(\%) \\
(-270 \text { to }-20 \text { days before the merger anno }\end{array}$ & 8.75 & 4.50 & 28.24 \\
\hline
\end{tabular}

Panel B: Firm-specific / governance variables

$\begin{array}{lccc}\text { Market value of equity (billions of yen) } & 173 & 38 & 499 \\ \text { Total assets (billions of yen) } & 274 & 57 & 590 \\ \text { Sales (billions of yen) } & 498 & 72 & 1508 \\ \text { Price-earnings ratio (times) } & 67.96 & 37.77 & 124.26 \\ \text { Debt / market value of the firm C } & 0.55 & 0.55 & 0.24 \\ \text { Loan / market value of the firm } & 0.24 & 0.21 & 0.18 \\ \text { Equity ownership structure: } & & & \\ \text { Bank \& insurance co. } & 0.31 & 0.31 & 0.18 \\ \text { Other corporations } & 0.30 & 0.25 & 0.18 \\ \text { Securities co. } & 0.02 & 0.01 & 0.02 \\ \text { Foreigners } & 0.05 & 0.02 & 0.09 \\ \text { Individuals } & 0.32 & 0.28 & 0.16 \\ \text { Ownership by top ten shareholders } & 0.46 & 0.43 & 0.13 \\ \text { Management ownership } & 0.04 & 0.01 & 0.08 \\ \text { Fraction of firms belonging to a keiretsu } & 0.40 & \text { n.a. } & \text { n.a. }\end{array}$

\footnotetext{
a The related merger is a merger involving two firms engaged in the same industry, measured by the 3-digit SIC codes.

$\mathrm{b}$ The value of common stock paid equals the number of acquiring firm's shares issued to the target times the acquiring firm's stock price per share at the end of the fiscal year preceding the merger announcement.

${ }^{c}$ Market value of the firm $=$ debt + market value of equity
} 


\section{Table III}

Mean and median cumulative abnormal returns (\%) for Japanese bidders around the announcement date $(\mathrm{AD})$ and the effective date $(\mathrm{ED})$ of mergers

The sample consists of 104 Japanese bidders listed on the Tokyo Stock Exchange for which an effective date of the merger fell between March 31, 1977 and December 1, 1990 and an announcement date could be obtained from any of the four daily newspapers: the Nihon Keizai Shimbun, Nikkei Sangyo Shimbun, Nikkei Ryutuu Shimbun, or Nikkei Kinyuu Shimbun. The abnormal return on a particular day is calculated by taking the difference between the return on the acquiring firm's shares and the return on one of the ten equally-weighted control portfolios with a similar Scholes and Williams (1977) beta estimate. $* * *$ and $* *$ indicate significance of the $\mathrm{t}$ statistic and of the sign-rank statistic at the 0.01 and 0.05 levels, respectively.

\begin{tabular}{llll}
\hline Interval & Mean & t-statistic & Median \\
\hline $\mathrm{AD}-60$ to $\mathrm{AD}-2$ & 2.10 & 1.34 & -0.43 \\
$\mathrm{AD}-1$ to $\mathrm{AD}$ & 1.41 & $2.67^{* * *}$ & $0.35^{* *}$ \\
$\mathrm{AD}-1$ to $\mathrm{AD}+1$ & 1.19 & $2.06^{* *}$ & 0.32 \\
$\mathrm{AD}-5$ to $\mathrm{AD}+5$ & 2.03 & $2.07^{* *}$ & 0.42 \\
$\mathrm{AD}+1$ to $\mathrm{ED}-1$ & -1.23 & -0.54 & -2.18 \\
$\mathrm{ED}-1$ to $\mathrm{ED}$ & 0.25 & 0.73 & 0.00 \\
$\mathrm{AD}-60$ to $\mathrm{ED}+20$ & -0.87 & -0.28 & -1.25 \\
\hline
\end{tabular}




\section{Table IV}

Two-day cumulative abnormal returns (\%) for Japanese bidders around the announcement date, stratified by merger-specific characteristics and the previous industry-adjusted stock return performance

The sample consists of 104 Japanese bidders listed on the Tokyo Stock Exchange for which an effective date of the merger fell between March 31, 1977 and December 1, 1990 and an announcement date could be obtained from the Nihon Keizai Shimbun, Nikkei Sangyo Shimbun, Nikkei Ryutuu Shimbun, or Nikkei Kinyuu Shimbun. The abnormal return on a particular day is calculated by taking the difference between the return on the acquiring firm's shares and the return on one of the ten equally-weighted control portfolios with a similar Scholes and Williams (1977) beta estimate. $* * *, * *$, and $*$ indicate significance of the t-statistic, of the sign-rank statistic, and of the Wilcoxon $\mathrm{z}$ - statistic at the $0.01,0.05$, and 0.10 levels, respectively.

\begin{tabular}{|c|c|c|c|}
\hline Subsample & Sample size & $\begin{array}{l}\text { Mean } \\
\text { (Median) }\end{array}$ & $\begin{array}{c}\text { t-statistic } \\
\text { (Wilcoxon-z statistic) }\end{array}$ \\
\hline
\end{tabular}

Panel A: By the industrial relatedness between the bidder and the target ${ }^{\mathrm{a}}$

$\begin{array}{lccc}\text { Related } & 57 & 2.28 & 2.79 * * * \\ & & (0.74)^{* *} & \\ \text { Unrelated } & 47 & 0.36 & 0.60 \\ \text { Difference } & & (0.00) & 1.90 * \\ & & (0.74) & (1.01)\end{array}$

Panel B: By the previous industry-adjusted stock returns (-270 to -20 days before the merger announcement)

$\begin{array}{lccc}\text { Positive } & 62 & 2.07 & 2.67 * * * \\ & & (0.74)^{* *} & \\ \text { Negative } & 42 & 0.43 & 0.71 \\ \text { Difference } & (-0.04) & \\ & & 1.64 & 1.67 * \\ & & (0.78) & (1.24)\end{array}$

Panel C: By the book value of target equity / the book value of bidder equity

\begin{tabular}{|c|c|c|c|}
\hline Larger than median & 52 & $\begin{array}{c}2.14 \\
(0.35)\end{array}$ & $2.36 * *$ \\
\hline Smaller than median & 52 & $\begin{array}{c}0.67 \\
(0.42)\end{array}$ & 1.28 \\
\hline Difference & & $\begin{array}{c}1.47 \\
(-0.07)\end{array}$ & $\begin{array}{c}1.40 \\
(-0.11)\end{array}$ \\
\hline
\end{tabular}


(Table IV continued)

\begin{tabular}{|c|c|c|c|}
\hline Subsample & Sample size & $\begin{array}{l}\text { Mean } \\
\text { (Median) }\end{array}$ & $\begin{array}{c}\text { t-statistic } \\
\text { (Wilcoxon-z statistic) }\end{array}$ \\
\hline
\end{tabular}

Panel D: By the value of transaction $\mathrm{b} /$ market value of bidder equity

Larger than median

Smaller than median

Difference
52

51
2.51

$(1.00)^{* *}$

0.32

(0.00)

2.19

(1.00)
$2.79 * * *$

0.62

$2.10 * *$

(1.15)

a The related merger is a merger involving two firms engaged in the same industry and the unrelated merger is a merger involving two firms engaged in different industries, measured by the 3-digit SIC codes.

$\mathrm{b}$ The value of the transaction is the sum of cash and common stock paid to the target. Common stock paid is measured by the number of acquiring firm's shares issued to target times the acquiring firm's stock price per share at the end of the fiscal year preceding the merger announcement. 


\section{Table V}

Two-day cumulative abnormal returns $(\%)$ for Japanese bidders around the announcement date, stratified by the previous industry-adjusted stock return performance (-270 to -20 days before the merger announcement) and the industrial relatedness between the bidder and the target ${ }^{\mathrm{a}}$

The sample consists of 104 Japanese bidders listed on the Tokyo Stock Exchange for which an effective date of the merger fell between March 31, 1977 and December 1, 1990 and an announcement date could be obtained from the Nihon Keizai Shimbun, Nikkei Sangyo Shimbun, Nikkei Ryutuu Shimbun, or Nikkei Kinyuu Shimbun. The abnormal return on a particular day is calculated by taking the difference between the return on the acquiring firm's shares and the return on one of the ten equally-weighted control portfolios with a similar Scholes and Williams (1977) beta estimate. $* * *, * *$, and $*$ indicate significance of the t-statistic, of the sign-rank statistic, and of the Wilcoxn z- statistic at the $0.01,0.05$, and 0.10 levels, respectively.

\begin{tabular}{|c|c|c|c|}
\hline & $\begin{array}{l}\text { Bad performance: } \\
\text { Negative adjusted stock return } \\
\text { \{t-statistic }\} \\
\text { (median) } \\
\text { \# of firms }\end{array}$ & $\begin{array}{l}\text { Good performance: } \\
\text { Positive adjusted stock return } \\
\{\text { t-statistic }\} \\
\text { (median) } \\
\text { \# of firms }\end{array}$ & $\begin{array}{l}\text { Difference } \\
\{\text { t-statistic }\} \\
\text { (median) } \\
\text { [Wilcoxon-z] }\end{array}$ \\
\hline Related & $\begin{array}{l}0.70 \\
\{0.83\} \\
(-0.12) \\
25\end{array}$ & $\begin{array}{l}3.50 \\
\{2.78\} * * * \\
(1.67)^{* *} \\
32\end{array}$ & $\begin{array}{l}-2.80 \\
\{-1.84\}^{*} \\
(-1.79) \\
{[-1.63]}\end{array}$ \\
\hline Unrelated & $\begin{array}{l}0.02 \\
\{0.03\} \\
(0.00) \\
17\end{array}$ & $\begin{array}{l}0.55 \\
\{0.68\} \\
(0.04) \\
30\end{array}$ & $\begin{array}{c}-0.53 \\
\{-0.44\} \\
(-0.04) \\
{[-0.19]}\end{array}$ \\
\hline $\begin{array}{l}\text { Difference } \\
\{\text { t-statistic }\} \\
\text { (median) } \\
\text { [Wilcoxon-z] }\end{array}$ & $\begin{array}{c}0.68 \\
\{0.56\} \\
(-0.12) \\
{[-0.08]}\end{array}$ & $\begin{array}{l}2.95 \\
\{1.97\} \\
(1.63) \\
{[1.44]}\end{array}$ & \\
\hline
\end{tabular}

a The related merger is a merger involving two firms engaged in the same industry and the unrelated merger is a merger involving two firms engaged in different industries, measured by the 3-digit SIC codes. 
Table VI

Two-day cumulative abnormal returns (\%) for Japanese bidders around the announcement date, stratified by firmspecific and governance characteristics

The sample consists of 104 Japanese bidders listed on the Tokyo Stock Exchange for which an effective date of the merger fell between March 31, 1977 and December 1, 1990 and an announcement date could be obtained from the Nihon Keizai Shimbun, Nikkei Sangyo Shimbun, Nikkei Ryutuu Shimbun, or Nikkei Kinyuu Shimbun. The abnormal return on a particular day is calculated by taking the difference between the return on the acquiring firm's shares and the return on one of the ten equally-weighted control portfolios with a similar Scholes and Williams (1977) beta estimate. $* * *, * *$ and $*$ indicate significance of the t-statistic, of the sign-rank statistic, and of the Wilcoxn z- statistic at the $0.01,0.05$, and 0.10 levels, respectively.

\begin{tabular}{|c|c|c|c|}
\hline Subsample & Sample size & $\begin{array}{c}\text { Mean } \\
\text { (Median) }\end{array}$ & $\begin{array}{c}\text { t-statistic } \\
\text { (Wilcoxon-z statistic) }\end{array}$ \\
\hline
\end{tabular}

Panel A: By leverage ratio (debt / market value of the firm ${ }^{\mathrm{a}}$ )

$\begin{array}{lccc}\text { Larger than median } & 52 & 1.75 & 3.03^{* * *} \\ & & (0.83)^{* * *} & \\ \text { Smaller than median } & 52 & 1.07 & 1.20 \\ & & (-0.18) & \\ \text { Difference } & 0.68 & 0.64 \\ & & (1.01) & (1.57)\end{array}$

Panel B: By bank loan ratio (loan / market value of the firm)

$\begin{array}{lccc}\text { Larger than median } & 52 & 2.74 & 3.44 * * * \\ & & (1.00)^{* * *} & \\ \text { Smaller than median } & 52 & 0.07 & 0.11 \\ & & (-0.18) & \\ \text { Difference } & 2.67 & 2.60^{* * *} \\ & & (1.18) & (2.58)^{* * *}\end{array}$

Panel C: By equity ownership held by top ten shareholders

\begin{tabular}{|c|c|c|c|}
\hline Larger than median & 52 & $\begin{array}{c}1.48 \\
(0.57)^{*}\end{array}$ & $2.19 * *$ \\
\hline Smaller than median & 52 & $\begin{array}{c}1.33 \\
(0.30)\end{array}$ & 1.63 \\
\hline Difference & & $\begin{array}{c}0.15 \\
(0.27)\end{array}$ & $\begin{array}{c}0.14 \\
(0.48)\end{array}$ \\
\hline
\end{tabular}

Panel D: By keiretsu membership

$\begin{array}{lccc}\text { Keiretsu } & 42 & 1.42 & 2.69^{* * *} \\ & & (0.77)^{* *} & \\ \text { Non-keiretsu } & 62 & 1.40 & 1.72^{*} \\ & & (-0.06) & \\ \text { Difference } & & 0.02 & 0.02 \\ & & (0.83) & (1.16)\end{array}$

a Market value of the firm $=$ debt + market value of equity 


\section{Table VII}

Two-day cumulative abnormal returns (\%) for Japanese bidders around the announcement date, stratified by keiretsu membership and the industrial relatedness between the bidder and the target ${ }^{\mathrm{a}}$

The sample consists of 104 Japanese bidders listed on the Tokyo Stock Exchange for which an effective date of the merger fell between March 31, 1977 and December 1, 1990 and an announcement date could be obtained from the Nihon Keizai Shimbun, Nikkei Sangyo Shimbun, Nikkei Ryutuu Shimbun, or Nikkei Kinyuu Shimbun. The abnormal return on a particular day is calculated by taking the difference between the return on the acquiring firm's shares and the return on one of the ten equally-weighted control portfolios with a similar Scholes and Williams (1977) beta estimate. $* * *$ and $* *$ indicate significance of the t-statistic, of the sign-rank statistic, and of the Wilcoxn z- statistic at the 0.01 and 0.05 levels, respectively.

\begin{tabular}{|c|c|c|c|}
\hline & $\begin{array}{l}\text { Keiretsu } \\
\{\text { t-statistic }\} \\
\text { (median) } \\
\text { \# of firms }\end{array}$ & $\begin{array}{c}\text { Non-keiretsu } \\
\text { \{t-statistic }\} \\
\text { (median) } \\
\text { \# of firms }\end{array}$ & $\begin{array}{l}\text { Difference } \\
\{\text { t-statistic } \\
\text { (median) } \\
\text { [Wilcoxon-z] }\end{array}$ \\
\hline Related & $\begin{array}{l}0.84 \\
\{1.06\} \\
(-0.02) \\
19\end{array}$ & $\begin{array}{l}2.99 \\
\{2.61\} * * \\
(0.81)^{* *} \\
38\end{array}$ & $\begin{array}{l}-2.15 \\
\{-1.54\} \\
(-0.83) \\
{[-1.65]}\end{array}$ \\
\hline Unrelated & $\begin{array}{l}1.90 \\
\{2.69\} * * \\
(1.13)^{* * *} \\
23\end{array}$ & $\begin{array}{l}-1.12 \\
\{-1.31\} \\
(-0.69) \\
24\end{array}$ & $\begin{array}{l}3.02 \\
\{2.72\} * * * \\
(1.82) \\
{[2.61]^{* * *}}\end{array}$ \\
\hline $\begin{array}{l}\text { Difference } \\
\{\text { t-statistic }\} \\
\text { (median) } \\
\text { [Wilcoxon-z] }\end{array}$ & $\begin{array}{l}-1.06 \\
\{-1.00\} \\
(-1.15) \\
{[-1.14]}\end{array}$ & $\begin{array}{l}4.11 \\
\{2.88\} * * * \\
(1.50) \\
{[2.32]^{* *}}\end{array}$ & \\
\hline
\end{tabular}

a The related merger is a merger involving two firms engaged in the same industry and the unrelated merger is a merger involving two firms engaged in different industries, measured by the 3-digit SIC codes. 
Table VIII

Regression estimates of two-day cumulative abnormal returns for Japanese bidders on explanatory variables

The sample consists of 104 Japanese bidders listed on the Tokyo Stock Exchange for which an announcement date of the merger fell between March 31, 1977 and December 1, 1990 and an event date could be obtained from the Nihon Keizai Shimbun, Nikkei Sangyo Shimbun, Nikkei Ryutuu Shimbun, or Nikkei Kinyuu Shimbun. The abnormal return on a particular day is calculated by taking the difference between the return on the acquiring firm's shares and the return on one of the ten equally-weighted control portfolios with a similar Scholes and Williams (1977) beta estimate. $* * *, * *$ and $*$ indicates significance of the $\mathrm{t}$-statistic at the $0.01,0.05$, and 0.10 levels, respectively.

\begin{tabular}{|c|c|c|c|c|c|c|c|}
\hline \multirow[b]{2}{*}{ Variables } & \multicolumn{7}{|c|}{ Regressions } \\
\hline & (1) & (2) & (3) & (4) & (5) & (6) & (7) \\
\hline Intercept & $\begin{array}{l}-0.0078 \\
(-0.72)\end{array}$ & $\begin{array}{l}-0.0067 \\
(-0.67)\end{array}$ & $\begin{array}{l}-0.0042 \\
(-0.19)\end{array}$ & $\begin{array}{l}0.0069 \\
(0.31)\end{array}$ & $\begin{array}{l}0.0144 \\
(0.58)\end{array}$ & $\begin{array}{l}0.0234 \\
(0.69)\end{array}$ & $\begin{array}{l}-0.0063 \\
(-0.18)\end{array}$ \\
\hline $\begin{array}{l}\text { Dummy }=1 \text { if bidder acquires } \\
\text { target in the same industry }\end{array}$ & $\begin{array}{l}0.0128 \\
(1.19)\end{array}$ & & & & & & \\
\hline $\begin{array}{l}\text { Previous bidder industry-adjusted } \\
\text { stock returns ( }-270 \text { to }-20 \text { days } \\
\text { before the merger announcement) }\end{array}$ & $\begin{array}{l}0.0458 \\
(2.53)^{* *}\end{array}$ & & & & & & \\
\hline $\begin{array}{l}\text { Dummy }=1 \text { if bidder acquires } \\
\text { target in the same industry \& } \\
\text { previous bidder industry-adjusted } \\
\text { stock return is positive }\end{array}$ & & $\begin{array}{l}0.0288 \\
(2.54)^{* *}\end{array}$ & & & $\begin{array}{l}0.0313 \\
(2.63)^{* * *}\end{array}$ & $\begin{array}{l}0.0238 \\
(2.00)^{* *}\end{array}$ & $\begin{array}{l}0.0221 \\
(1.82)^{*}\end{array}$ \\
\hline $\begin{array}{l}\text { Value of transaction }{ }^{\mathrm{a}} / \\
\text { market value of bidder equity }\end{array}$ & $\begin{array}{l}0.0385 \\
(1.85)^{*}\end{array}$ & $\begin{array}{c}0.0429 \\
(2.11)^{* *}\end{array}$ & & & $\begin{array}{c}0.0485 \\
(2.41)^{* *}\end{array}$ & $\begin{array}{c}0.0397 \\
(1.97)^{* *}\end{array}$ & $\begin{array}{c}0.0389 \\
(1.94)^{*}\end{array}$ \\
\hline $\begin{array}{l}\text { Target equity ownership held by } \\
\text { bidders prior to the merger } \\
\text { announcement }\end{array}$ & $\begin{array}{l}0.0002 \\
(0.81)\end{array}$ & $\begin{array}{l}0.0002 \\
(0.87)\end{array}$ & & & $\begin{array}{l}0.0001 \\
(0.28)\end{array}$ & $\begin{array}{l}0.0002 \\
(0.84)\end{array}$ & $\begin{array}{l}0.0002 \\
(1.00)\end{array}$ \\
\hline $\begin{array}{l}\text { Leverage ratio } \\
(\text { debt / market value of the firmb) }\end{array}$ & & & $\begin{array}{l}0.0455 \\
(1.89)^{*}\end{array}$ & & & & \\
\hline $\begin{array}{l}\text { Loan ratio (borrowings from } \\
\text { financial institutions / } \\
\text { market value of the firm) }\end{array}$ & & & & $\begin{array}{l}0.0838 \\
(2.76)^{* * *}\end{array}$ & $\begin{array}{c}0.0749 \\
(2.52)^{* *}\end{array}$ & $\begin{array}{c}0.0597 \\
(2.08)^{* *}\end{array}$ & $\begin{array}{c}0.0602 \\
(2.11)^{* *}\end{array}$ \\
\hline $\begin{array}{l}\text { Other debt ratio (other debt / } \\
\text { market value of the firm) }\end{array}$ & & & & $\begin{array}{l}0.0003 \\
(0.01)\end{array}$ & $\begin{array}{l}-0.0197 \\
(-0.53)\end{array}$ & $\begin{array}{l}0.0023 \\
(0.06)\end{array}$ & $\begin{array}{l}0.0173 \\
(0.47)\end{array}$ \\
\hline $\begin{array}{l}\text { Dummy = } 1 \text { if bidder belongs to } \\
\text { the keiretsu group }\end{array}$ & & & $\begin{array}{l}-0.0088 \\
(-0.76)\end{array}$ & $\begin{array}{l}-0.0100 \\
(-0.88)\end{array}$ & $\begin{array}{l}0.0044 \\
(0.37)\end{array}$ & $\begin{array}{l}0.0091 \\
(0.78)\end{array}$ & $\begin{array}{l}0.0095 \\
(0.78)\end{array}$ \\
\hline $\begin{array}{l}\text { Bidder equity ownership held by } \\
\text { top ten shareholders }\end{array}$ & & & $\begin{array}{l}-0.0001 \\
(-0.17)\end{array}$ & $\begin{array}{l}-0.0002 \\
(-0.45)\end{array}$ & $\begin{array}{l}-0.0007 \\
(-1.65)\end{array}$ & & \\
\hline $\begin{array}{l}\text { Bidder equity ownership held by } \\
\text { financial institutions }\end{array}$ & & & & & & $\begin{array}{l}-0.0006 \\
(-1.32)\end{array}$ & $\begin{array}{l}-0.0003 \\
(-0.61)\end{array}$ \\
\hline $\begin{array}{l}\text { Bidder equity ownership held by } \\
\text { other corporations }\end{array}$ & & & & & & $\begin{array}{c}-0.0009 \\
(-2.10)^{* *}\end{array}$ & $\begin{array}{l}-0.0006 \\
(-1.23)\end{array}$ \\
\hline Management equity ownership & & & & & & $\begin{array}{l}-0.0002 \\
(-0.21)\end{array}$ & \\
\hline
\end{tabular}

(Table VIII continued) 
(Table VIII continued)

\begin{tabular}{|c|c|c|c|c|c|c|c|}
\hline \multirow[b]{2}{*}{ Variables } & \multicolumn{7}{|c|}{ Regressions } \\
\hline & (1) & (2) & (3) & (4) & (5) & (6) & (7) \\
\hline $\begin{array}{l}\text { Management equity ownership } \\
(0 \text { to } 5 \%)^{\mathrm{c}}\end{array}$ & & & & & & & $\begin{array}{l}-0.0023 \\
(-0.48)\end{array}$ \\
\hline $\begin{array}{l}\text { Management equity ownership } \\
(5 \text { to } 10 \%)^{c}\end{array}$ & & & & & & & $\begin{array}{l}0.0071 \\
(0.72)\end{array}$ \\
\hline $\begin{array}{l}\text { Management equity ownership } \\
(10 \text { to } 15 \%)^{\mathrm{c}}\end{array}$ & & & & & & & $\begin{array}{l}0.0016 \\
(0.12)\end{array}$ \\
\hline $\begin{array}{l}\text { Management equity ownership } \\
(15 \text { to } 20 \%)^{c}\end{array}$ & & & & & & & $\begin{array}{c}0.0233 \\
(2.35)^{* *}\end{array}$ \\
\hline $\begin{array}{l}\text { Management equity ownership } \\
(\text { Above } 20 \%)^{c}\end{array}$ & & & & & & & $\begin{array}{l}-0.0022 \\
(-1.30)\end{array}$ \\
\hline $\begin{array}{l}\text { F-statistic } \\
\text { (p-value) } \\
\text { Adjusted } \mathrm{R}^{2}(\%)\end{array}$ & $\begin{array}{c}3.59 \\
(0.01) \\
9.22\end{array}$ & $\begin{array}{c}4.18 \\
(0.01) \\
8.55\end{array}$ & $\begin{array}{c}1.19 \\
(0.32) \\
0.06\end{array}$ & $\begin{array}{c}1.92 \\
(0.11) \\
3.44\end{array}$ & $\begin{array}{c}3.20 \\
(0.00) \\
13.12\end{array}$ & $\begin{array}{l}2.57 \\
(0.01) \\
12.38\end{array}$ & $\begin{array}{l}2.55 \\
(0.01) \\
16.73\end{array}$ \\
\hline Sample size & 103 & 103 & 104 & 104 & 103 & 101 & 101 \\
\hline
\end{tabular}

a The value of the transaction is the sum of cash and common stock paid to the target. Common stock paid is measured by the number of acquiring firm's shares issued to target times the acquiring firm's stock price per share at the end of the fiscal year preceding the merger announcement.

$\mathrm{b}$ Market value of the firm $=$ debt + market value of equity.

$\mathrm{c}$ Management equity ownership (0 to $5 \%$ ), Management equity ownership (5 to $10 \%$ ), Management equity ownership (10 to 15\%), Management equity ownership (15 to 20\%), and Management equity ownership (Above $20 \%$ ) are piecewise linear variables of management equity ownership of the bidding firms with turning points of 5 , 10,15 , and $20 \%$, respectively. 